\title{
Bibliometric Analysis of the Mass Transport in a Gas Diffusion Layer in PEM Fuel Cells
}

\author{
Blandy Pamplona Solis 1,2®, Julio César Cruz Argüello 2,*®D, Leopoldo Gómez Barba 1,* , \\ Mayra Polett Gurrola ${ }^{3}$, , Zakaryaa Zarhri $^{3}{ }^{(1)}$ and Danna Lizeth TrejoArroyo ${ }^{3}$ \\ 1 Information Systems Department, University of Guadalajara, Zapopan 45100, Mexico; \\ bpamplona@itchetumal.edu.mx \\ 2 Tecnológico Nacional de México/I. T. Chetumal, Chetumal 77013, Mexico \\ 3 CONACYT-Tecnológico Nacional de México/I. T. Chetumal, Chetumal 77013, Mexico; \\ polett@itchetumal.edu.mx (M.P.G.); z.zarhri@itchetumal.edu.mx (Z.Z.); danna@itchetumal.edu.mx (D.L.T.) \\ * Correspondence: jcruz@itchetumal.edu.mx (J.C.C.A.); leopoldo.gbarba@academicos.udg.mx (L.G.B.); \\ Tel.: +52-442-3290-609 (J.C.C.A.); +52-331-4343-714 (L.G.B.)
}

Received: 6 November 2019; Accepted: 20 November 2019; Published: 26 November 2019

\begin{abstract}
The growth trend of publications in the field of Proton Exchange Membrane Fuel Cell (PEMFC) was analyzed using bibliometric techniques to the identification of the areas with significant development and the orientations that have guided the research on energy cells. This study extracted the data from Scopus and Web of Science (WoS) databases to compare the bibliometric indicators of the published productions. In spite of bibliometric analysis advantages to knowing about the trends in a study area, this research requires methods to support the investigation process through the selection of a relevant bibliographic portfolio. This study applied the Methodi Ordinatio that provides a new approach to achieve it. A proposed list of the articles ranked by InOrdinatio is presented to compose the final portfolio. The obtained results in the research sub-theme of the Mass Transport in Gas Diffusion Layer (GDL) confirm the complexity in the study area by presenting erratic patterns of exponential growth. United States, China, and Japan are the leading countries on PEMFC publications. These countries have in common a strong spending by the business sector for R\&D, and their gross domestic product is greater than $2 \%$.
\end{abstract}

Keywords: PEM Fuel Cell; GDL; mass transport; bibliometric analysis; Methodi Ordinatio

\section{Introduction}

The use of fossil fuels for energy generation damage the environment due to the high emission of pollutants such as $\mathrm{CO}_{2}, \mathrm{NO}_{2}$ and $\mathrm{SO}_{2}[1,2]$. Therefore, there are worldwide efforts to develop alternative energy sources to reduce the greenhouse effect and other problems derived from air pollution [3-6].

Hydrogen is a zero-emissions potential vector of energy that has been studied over the last 30 years. In this sense, alternative technologies have been developed in the generation of electricity using hydrogen like the so-called Proton Exchange Membrane Fuel Cells (PEMFC) [7,8].

Fuel cells are devices that produce electricity through the electrochemical reaction of oxidation, where the used fuel is hydrogen, and the oxidant is pure oxygen or air. The main elements of a PEMFC are the cathode, the anode and the electrolyte membrane. Hydrogen fuel is provided to the anode, and the oxygen is transferred across the cathode. The oxidation of hydrogen produces protons and electrons. Protons pass over the electrolyte membrane, and electrons are transported to the cathode through an external circuit. During the reaction process, the fuel cell produces electricity, water, and heat [9-11]. Research on the issue of cells have become popular because they have demonstrated 
characteristics of scalability, reliability, low or zero pollutants emission and high efficiency concerning internal combustion engines [12-14].

Bibliometrics is a resource used to quantify the progress of science and scientific researches. The bibliometric analysis is used to establish indicators to notice the state of knowledge of a specific area by accounting for a particular set of publication data [15]. It is also a tool that supports the understanding of how science progresses. Therefore, it is essential to notice growth in the patterns, the development of a scientific field, the productivity of authors/institutions/countries, as well as the prospective of the investigated area [16-18].

The bibliometric study by Huang et al. indicated a prolific growth in the number of articles and patents of fuel cells during the period from 1991 to 2010, showing that there are few countries where publications and patents are concentrated [19-22]. The Organization for Economic Co-operation and Development (OECD) has found similar behavior patterns on PEMFC scientific publications, having significant growth in the 1990s. The OECD bibliometric study conducted during the period from 1990 to 2000 described the scientific activity of seven main types of cells: Alkaline Fuel Cell (AFC), Direct Methanol Fuel Cell (DMFC), Molten Carbonate Fuel Cell (MCFC), Phosphoric Acid Fuel Cell (PAFC), Proton Exchange Membrane Fuel Cell (PEMFC), Solid Oxide Fuel Cell (SOFC) and Unitized Regenerative Fuel Cell (URFC). This found that PEM, solid oxide, and molten carbonate cells together had a productivity of $75 \%$ of total publications [22]. According to the study conducted by Cindrella [20], the topic PEMFC increased its position as a keyword used in papers between the years 1992-2011. In this way, the importance of the PEMFC can be observed in the investigations about clean energy sources. [15] It is important to highlight the importance of the topic of fuel cells in scientific production in countries such as China, where energy and fuel research has as recurring topics: "SOFC", "hydrogen", "PEMFC" and "hydrogen production" [23].

The increase of fuel cell publications has shown an S-shaped curve characteristic of sigmoidal growth, based on bibliometric reports that this trend remained in the exponential phase until 2010 [15,20]. In spite of PEMFCs being the most studied field of fuel cell technology research [24,25], there are few bibliometric analyses focused exclusively on the topic and the period of study is only until the year of 2012.

Research has been conducted to improve fuel cell performance due to the concentration losses. Improving the quality of the gas diffusion layer and mass transport can reduce these losses [7,19,26-29]. Although there is interest in PEMFCs optimization, the selection of bibliographic material to comprise an adequate portfolio in a particular area is a protracted work for the researchers due to the vast publications presented by the scientific databases. The Methodi Ordinatio is a portfolio selection methodology proposed by Pagani et al. which helps to choose the more relevant papers based on three main criteria: the impact factor of the journal in which the paper was published, the number of citations and the year of publication [30,31].

In this sense, the goals of the present article aim to (i) describe quantitively the PEMFC trend research space during the period from 1970 to 2019 in two databases (Web of Science (WoS), Scopus); (ii) achieve an adequate portfolio with the most pertinent articles in the study of "GDL and Mass Transport" field applying bibliometric techniques and the Methodi Ordinatio [30,31], and (iii) recognize relevant subjects in the development of "GDL and Mass Transport" researches over the last ten years. Likewise, this study is an opportunity to support new research by providing quantitative and qualitative data in the PEMFC area.

\section{Materials and Methods}

A Proton Exchange Membrane Fuel Cell bibliometric study was the first step to help understand the area behavior through extract data from Scopus and Web of Science (WoS) databases. The selection of these databases was due to their importance (WoS more than Scopus) for searching literature [32-35]. The search period spans from January 1970 till September 2019. The set of keywords and the Boolean 
operator was determined as ("Fuel Cell *") AND (PEM OR "Proton Exchange Membrane" OR "Polymer Electrolyte Membrane"). A total of 30,820 articles were found in Scopus and 31,874 in WoS.

The analysis of the recurrence of keywords in the published papers can be used to know the research trends in certain themes of the PEMFC. Through the tool VOSviewer [36,37] the map of co-occurrence of text was made (Figure 1). The words "Cell", "Membrane", "Catalyst" and "Model" were the most recurrently appearing in the titles and summaries of the publications. This analysis confirmed that GDL and mass transport topics appeared among the first 50 most used keywords, and support this research.

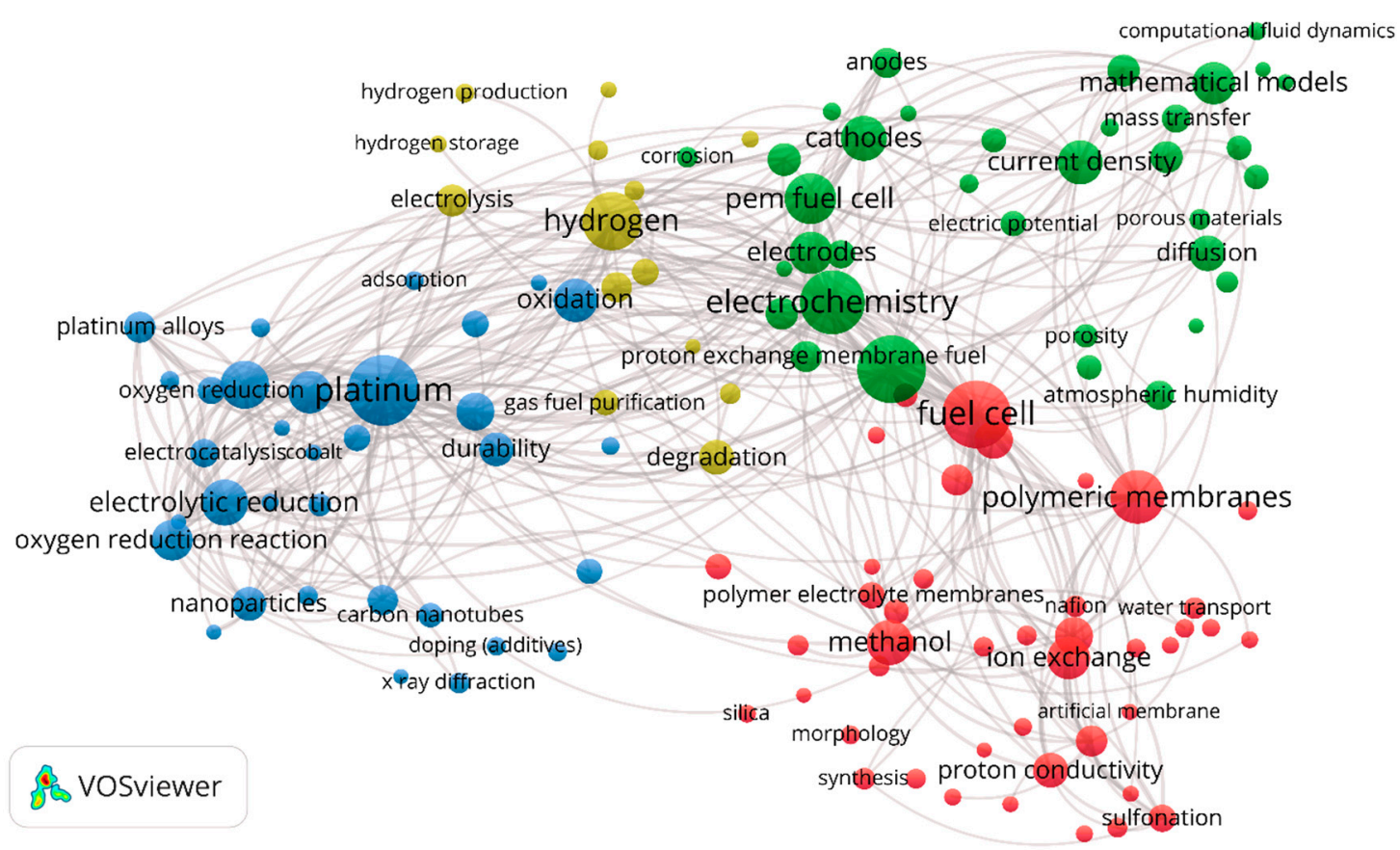

Figure 1. Bibliometric map created by VOSviewer based on "PEMFC" (Proton Exchange Membrane Fuel Cell) keyword co-occurrence.

The selection of a bibliographic portfolio to support the mass transport in a gas diffusion layer in PEM fuel cell research was conducted using the Methodi Ordinatio. Figure 2 shows the nine phases of this methodology.

\begin{tabular}{|l|l|}
\hline 1 & - Establish the intention of the research \\
\hline 2 & - Exploratory preliminary research with keywords in \\
\hline 3 & - Definition and combination of keywords and databases \\
\hline 4 & - Final search in the databases \\
\hline 5 & - Filtering procedures \\
\hline 6 & - Identification of impact factor, year of publication and \\
\hline 7 & - Ranking the papers using the InOrdinatio \\
\hline $\mathbf{8}$ & - Finding the full papers \\
\hline 9 & - Final reading and systematic analysis of the papers \\
\hline
\end{tabular}

Figure 2. The phases of the methodology Methodi Ordinatio. Source: Pagani et al. (2018) [31]. 
The next sequence describes the implementation of Methodi Ordinatio to achieve the objective of this study:

1. Phase 1. The intention of research: The purpose of this research is "Mass Transport in a Gas Diffusion Layer in PEM Fuel Cells".

2. Phase 2. Preliminary research with keywords: The first approach for the search was "PEM" AND "Fuel Cell" AND "Mass Transport" AND "Gas Diffusion Layer". This test aids in defining a set of keywords for the final search through analysis of relevant words in the articles.

3. Phase 3. Final decision on keyword combinations and databases: Based on the preliminary articles, new words appeared as keywords used commonly by the authors: "Polymer Electrolyte", "Proton Exchange Membrane", "Transport Phenomena", "GDL", "Mass Transfer", "Model", "Simulation", "PEMFC", “Modeling", "Fuel Cells", “CFD", “Computational Fluid Dynamics". After analyzing them, a set of keywords was defined for the final search (Figure 3). WOS and Scopus were selected as databases.

4. Phase 4. Final search in the databases: The string search was comprised of words using wildcard symbols and Boolean operators. Final keywords query was defined as: ("Fuel Cell *") AND ("PEM" OR "Proton Exchange Membrane OR Polymer Electrolyte Membrane") AND ("GDL" OR "Gas Diffusion Layer") AND ("Mass Transfer" OR "Transport Phenomena" OR "Mass Transport") AND ("Model *" OR "Simulation"). The results obtained were exported in csv and bibText format for later analysis with tools such as VOSviewer and reference manager Mendeley. A total of 363 articles were found in Scopus and 416 in WoS.

5. Phase 5. Filtering procedures: A gross portfolio was obtained in the previous phase. Afterward, a filtering procedure is necessary to obtain the most relevant articles. Figure 3 shows the four filters applied: (i) Eliminate duplicates, remaining 525. (ii) Keep only with works categorized as article, 413 remain. (iii) The research period was set up from 2008 to 2019. After the filter, 327 articles were left. (iv) Apply the index InOrdinatio, items with an InOrdinatio equal or greater than 72 were selected to comprise the final portfolio.

6. Phase 6. Identification of the impact factor, the year of publication, and the number of citations: Through the results extracted from both databases (WoS, Scopus), the year of publication and the number of citation criterion was acquired. The impact factor of the journal was obtained from the Clarivate Analytics Incites Journal Citation Reports [38] or the Scopus Source List [39] web site.

7. Phase 7. Ranking the papers using the InOrdinatio: After the phases 1 to 6 were conducted, the Methodi Ordinatio applies the index InOrdinatio using the Equation (1) presented by Pagani et al. (2015). This coefficient considers the total of citations $\left(\sum C i\right)$, the normalized impact factor $(I F / 1000)$, a weighting factor $(\propto)$ whose value is set by the researcher between a range 1 to 10 , the research year, and the publication year to ranking the articles.

$$
\text { InOrdinatio }=\left(\frac{I F}{1000}\right)+\propto *[10-(\text { ResearchYear }- \text { PublishYear })]+\left(\sum C i\right)
$$

where:

IF = impact factor (JCR, CiteScore, SJR, or SNIP).

$\propto=$ coefficient (1 to 10 ) value of the importance to the year of the article.

ResearchYear $=$ year in which the research is being done.

PublishYear = year the article was published.

$\sum C i=$ total number of citations of the article.

This study applied InOrdinatio equation with an alpha $(\alpha)$ equal to seven to take into consideration recent important published articles that have citations. The final portfolio proposed in this study is shown in Section 3.2. 
8. Phase 8. Finding the full papers: Once the list of articles ranking by InOrdinatio is obtained, the gathering of papers may be done through a reference manager such as Zotero, Mendeley or Citavi. If the full text is not available, the researcher may interchange with the next on the list or if the paper is very relevant may purchase it.

9. Phase 9. Final reading and systematic analysis of the papers: A systematic review is a laborious and wide-spread work; the Methodi Ordinatio provides an order list to help the researcher choose the most relevant papers according to his/her selection criteria and final reading of the selected articles.

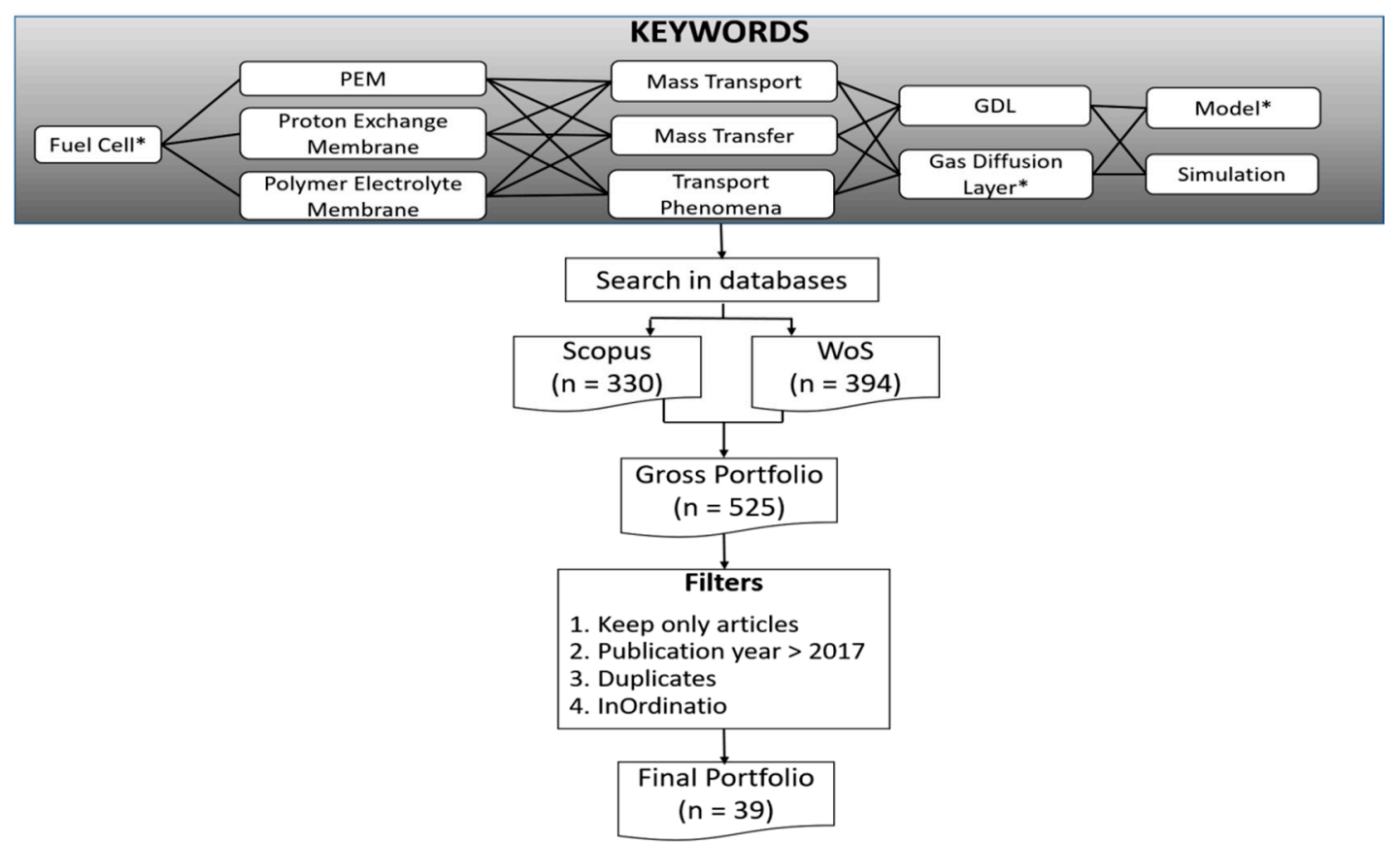

Figure 3. Retrieval and filtering procedures used to obtain the final portfolio.

As the goal of this paper is the use of bibliometric techniques and inOrdinatio equation to evidence the support of these tools finding an adequate portfolio with the most pertinent articles on the study of "GDL and Mass Transport" fields; the results of the phase nine will be published in a future paper which presents the findings for the theme.

\section{Results and Discussion}

The obtained results show the tendency growth in PEMFC; this section describes a comparison of the last ten years of the publication percentage of the mass transport in gas diffusion layer. Likewise, a relevant suggested portfolio was obtained through the index InOrdinatio.

\subsection{Bibliometric Analysis of PEM Fuel Cells}

The goal of the first search was researching articles containing "PEM" and "Fuel cell(s)" in the title, abstract, and keywords published until 2019. The total of published articles found between the years 1970 to 2019 was 30,856 in Scopus, and 31,901 in WOS. The first article indexed in Scopus was published in the Society of Automotive Engineers (SAE) Technical Papers in 1969. The highest scientific production years were 2011 with 2231 publications in Scopus and the year 2018 with 2244 in WoS. Clearly, Figure 4 shows the ascending growth of the number of papers with a sigmoidal behavior for the two databases where it can be observed the stages defined by the Price Law (precursors, exponential, linear, collapse) [40]. 


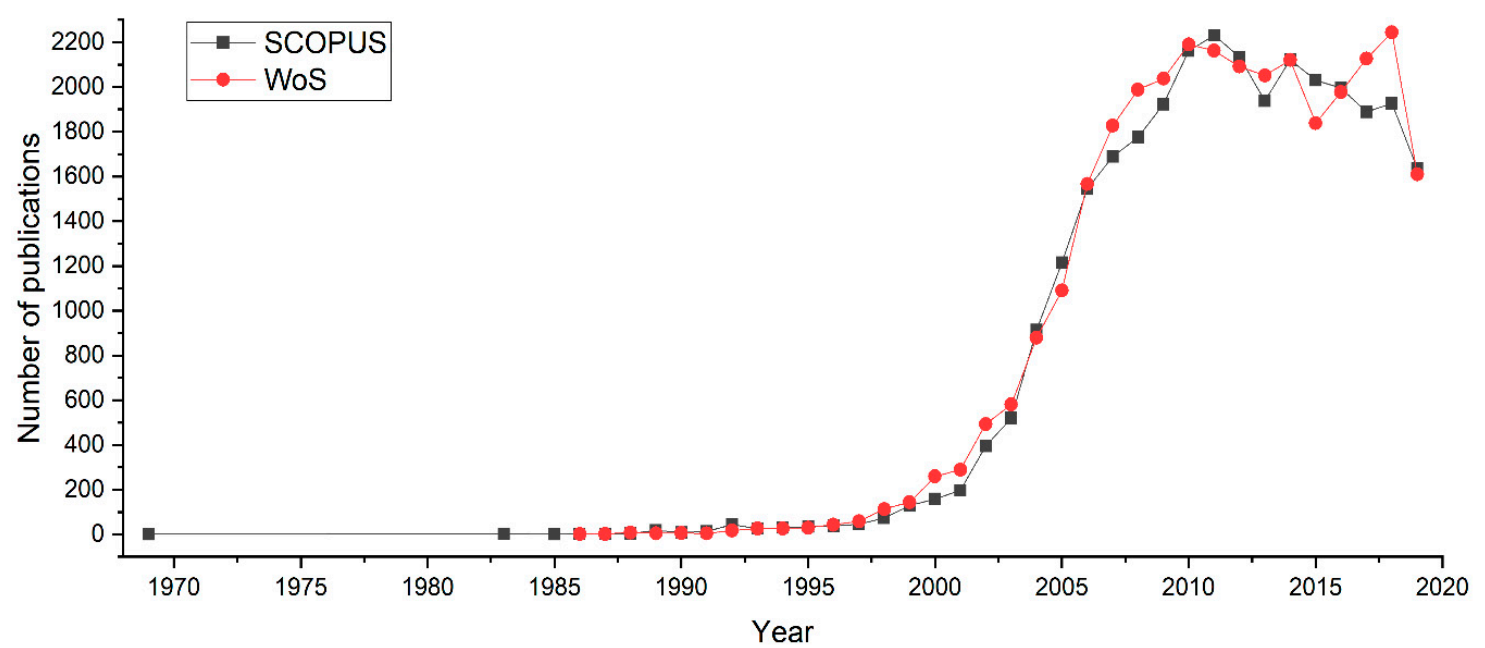

Figure 4. The number of PEMFC publications per year.

During the 50 years of scientific production on the subject of PEMFC, 71,458 authors have contributed to the generation of 31,901 publications according to the results generated in the WOS query. Figure 5 shows the growth trend of the scientific population between the period of 1969 and 2009, reaching the highest amount in 2014 with 10,256 authors. This behavior demonstrates the boom in the issue of fuel cells, considering that in recent years, the maturity in knowledge has been reached by presenting more gradual growth.

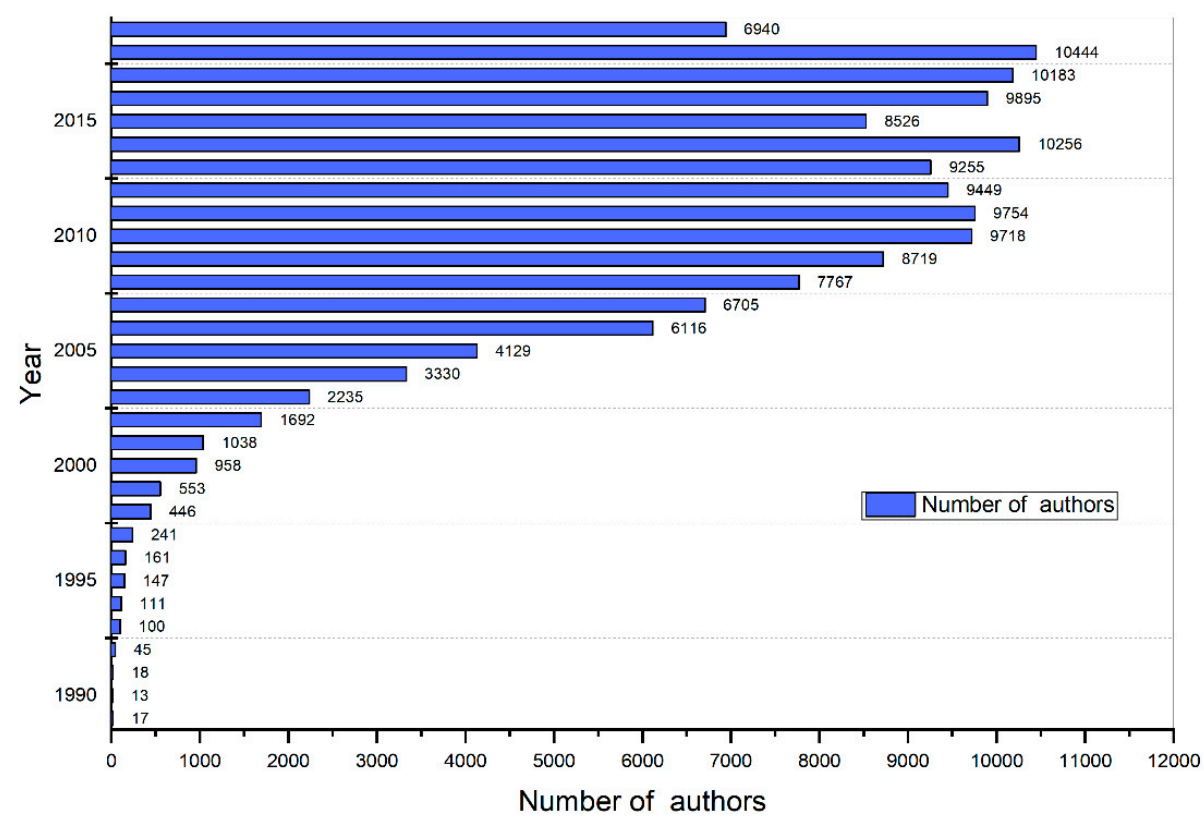

Figure 5. Scientific population per year 1989-2019 (Web of Science (WOS)).

Table 1 shows the list of the 30 countries with the highest contribution in the research of the PEMFC; United States, China, and Japan together have almost $50 \%$ of the production of the articles worldwide generated. The United States ranks the first place with a total of 6871 publications, followed by China with 5284 and in the third place Japan with 2431. The results are expected since national policies supported the investment made in research and development in these countries to obtain sufficient funds for the growth of fuel cells during these years [23,41-43]. Likewise, the investment expenditure in the first three leading countries represents more than $2 \%$ of the gross domestic product [44]. 
Table 1. Top 30 of the most productive countries in PEMFC publications.

\begin{tabular}{|c|c|c|c|c|c|c|c|}
\hline No. & Country & Scopus & WoS & No. & Country & Scopus & WoS \\
\hline 1 & United States & 6871 & 4627 & 16 & Malaysia & 346 & 205 \\
\hline 2 & China & 5284 & 7334 & 17 & Brazil & 332 & 263 \\
\hline 3 & Japan & 2431 & 1745 & 18 & Mexico & 316 & 261 \\
\hline 4 & South Korea & 2339 & 2239 & 19 & Australia & 302 & 262 \\
\hline 5 & Canada & 2120 & 1686 & 20 & Switzerland & 299 & 262 \\
\hline 6 & Germany & 1939 & 1558 & 21 & Thailand & 292 & 210 \\
\hline 7 & France & 1502 & 1130 & 22 & Russian Federation & 281 & 295 \\
\hline 8 & India & 1211 & 993 & 23 & Singapore & 266 & 221 \\
\hline 9 & Taiwan & 1143 & 971 & 24 & Sweden & 221 & 195 \\
\hline 10 & Italy & 1125 & 886 & 25 & Greece & 217 & 165 \\
\hline 11 & United Kingdom & 994 & 1264 & 26 & Netherlands & 206 & 158 \\
\hline 12 & Iran & 752 & 654 & 27 & South Africa & 201 & 154 \\
\hline 13 & Spain & 736 & 615 & 28 & Romania & 158 & 96 \\
\hline 14 & Turkey & 422 & 385 & 29 & Algeria & 142 & 80 \\
\hline 15 & Denmark & 402 & 345 & 30 & Poland & 135 & 95 \\
\hline
\end{tabular}

The worldwide distribution of leader countries is presented in Figure 6. The Asian continent is the highest publisher with 14,220 items, Europe is the continent with more participating countries, and South America and Africa have the lowest contribution in publications and publisher countries.

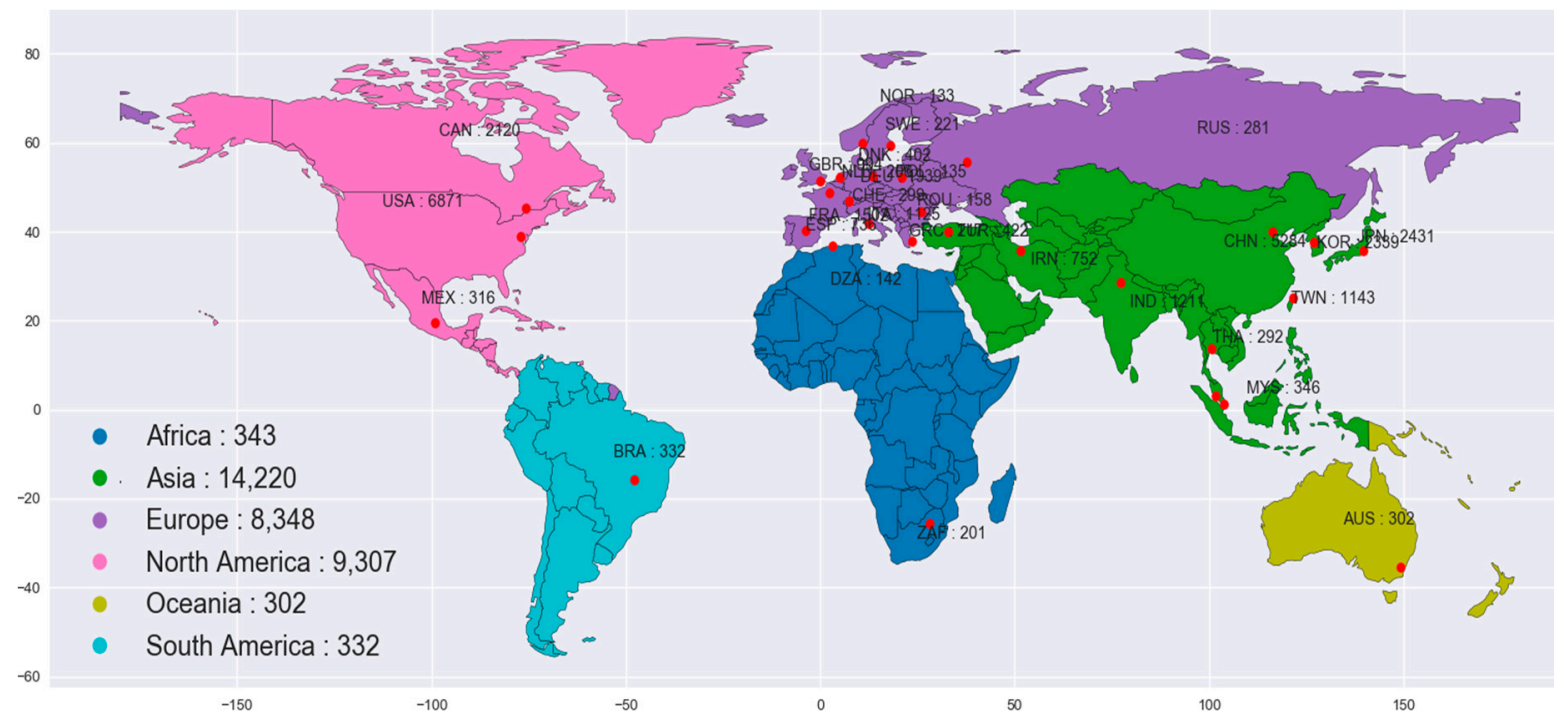

Figure 6. Top 30 countries map in PEMFC publications.

\subsection{Mass Transport in a Gas Diffusion Layer Bibliographic Portfolio}

Once the magnitude of the research in the PEMFC topic was determined through bibliometric techniques, two queries were applied to find the Mass Transport in a Gas Diffusion Layer gross portfolio following the Methodi Ordinatio. The searching string used in the Scopus was: (TITLE-ABS-KEY ("FUEL CELL*") AND TITLE-ABS-KEY ("PEM" OR “PROTON EXCHANGE MEMBRANE" OR "POLYMER ELECTROLYTE MEMBRANE") AND TITLE-ABS-KEY ("GDL" OR “GAS DIFFUSION LAYER*) AND TITLE-ABS-KEY ("MASS TRANSPORT" OR “MASS TRANSFER" OR “TRANSPORT PHENOMENA") AND TITLE-ABS-KEY (“SIMULATION" OR “MODEL*”)). The used query in WoS included all databases and not only its main collection: (TOPIC: ("FUEL CELL *") AND TOPIC: (PEM OR "PROTON EXCHANGE MEMBRANE" OR “POLYMER ELECTROLYTE MEMBRANE" ) AND TOPIC: ("GDL" OR “GAS DIFFUSION LAYER*) AND TOPIC: ("MASS TRANSPORT" OR "MASS TRANSFER" OR “TRANSPORT PHENOMENA") AND TOPIC: ("SIMULATION" OR “MODEL") Timespan: All years databases: WOS, BCI, DIIDW, KJD, RSCI, SCIELO Search language = Auto). 
A total of 724 articles comprised the gross portfolio. Table 2 shows the number of papers discarded with the four criteria established in the Ordinatio Method phase five. After the filtering process was executed, 39 most relevant articles remained. Table 3 presents the ranking list with an InOrdinatio index $\alpha=7$ of the final portfolio. Two additional columns were included in this table: The position of the articles with $\alpha=5$ and $\alpha=10$.

Table 2. The number of papers before and after the filtering procedures.

\begin{tabular}{|c|c|c|c|c|}
\hline Filtering Procedure & Gross Selected Articles & Articles Cross of & Articles Remained & $\%$ \\
\hline WoS & 394 & & & \\
\hline Scopus & 330 & & & \\
\hline Gross portfolio total papers & 724 & & & 100 \\
\hline Duplicates & & 199 & 525 & 72.5 \\
\hline Reviews, book chapters, conference papers & & 112 & 413 & 57.0 \\
\hline Articles published before 2008 & & 86 & 327 & 45.2 \\
\hline InOrdinatio $<72$ & & 288 & 39 & 5.4 \\
\hline Total papers discarded & & 671 & & 92.7 \\
\hline Total papers considered for portfolio & & 39 & & \\
\hline
\end{tabular}

Table 3. The list of the articles ranked by InOrdinatio to compose the final portfolio.

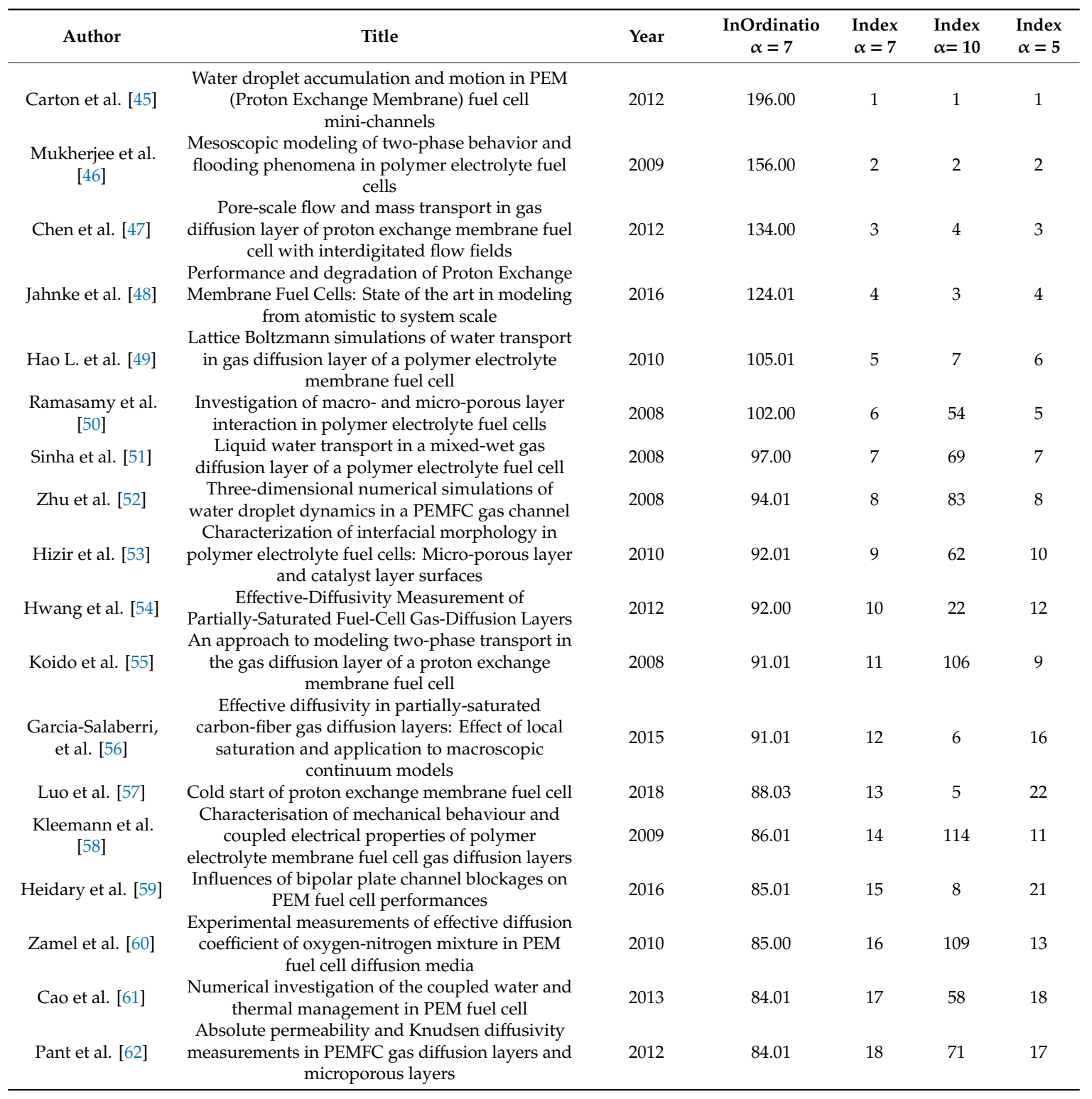


Table 3. Cont.

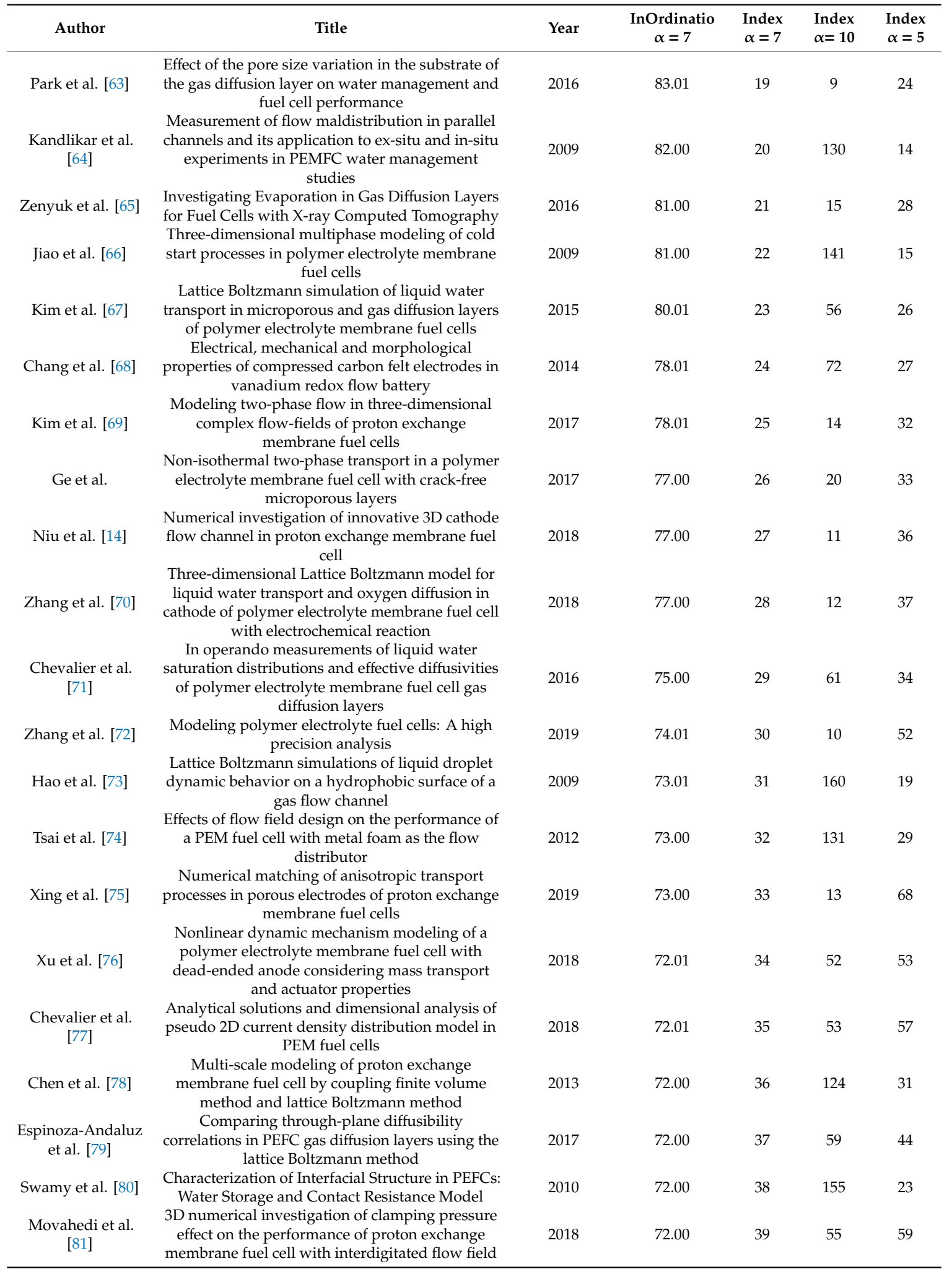

Table 3 shows how the position of the articles changes in the ranking list, depending on the alpha used in the InOrdinatio equation. An alpha near to one $(\alpha=1)$ generates portfolios with classic articles, but if recent papers are more important for the research, then the value of alpha should be closer to 10. One example is the case of Ramasamy's article [50] which has the 6th position with an alpha equal to 
7 , but its position changes to 54 applying an alpha equal to 10 . In addition, the researchers have the option to select a variable number of articles for the index generated by InOrdinatio and comprise the final portfolio.

The list of 39 articles presented in this study is a no restrictive proposal. Its functionality is to support research and suggest the application of a multicriteria method like InOrdinatio to achieve a relevant and pertinent bibliographic portfolio. The list helps the researchers in their investigation process during the systematic analysis of literature, making the work easier.

\subsection{Relevant Subjects in the Development of "GDL and Mass Transport" Research}

In this section, a bibliometric study was executed based on the data of 412 articles corresponding to the bibliographic portfolio after applying filter number two. It presents quantitative information to complement knowledge about the development of the research area.

The analysis of keyword co-occurrence through VOSviewer software displays the most frequent topics used in mass transport in gas diffusion layer research. Figure 7 shows the themes developed over the years. The keywords "computational fluid dynamics", "models", "simulation" demonstrate the tendency of applying computational resources to support new studies in the last years.

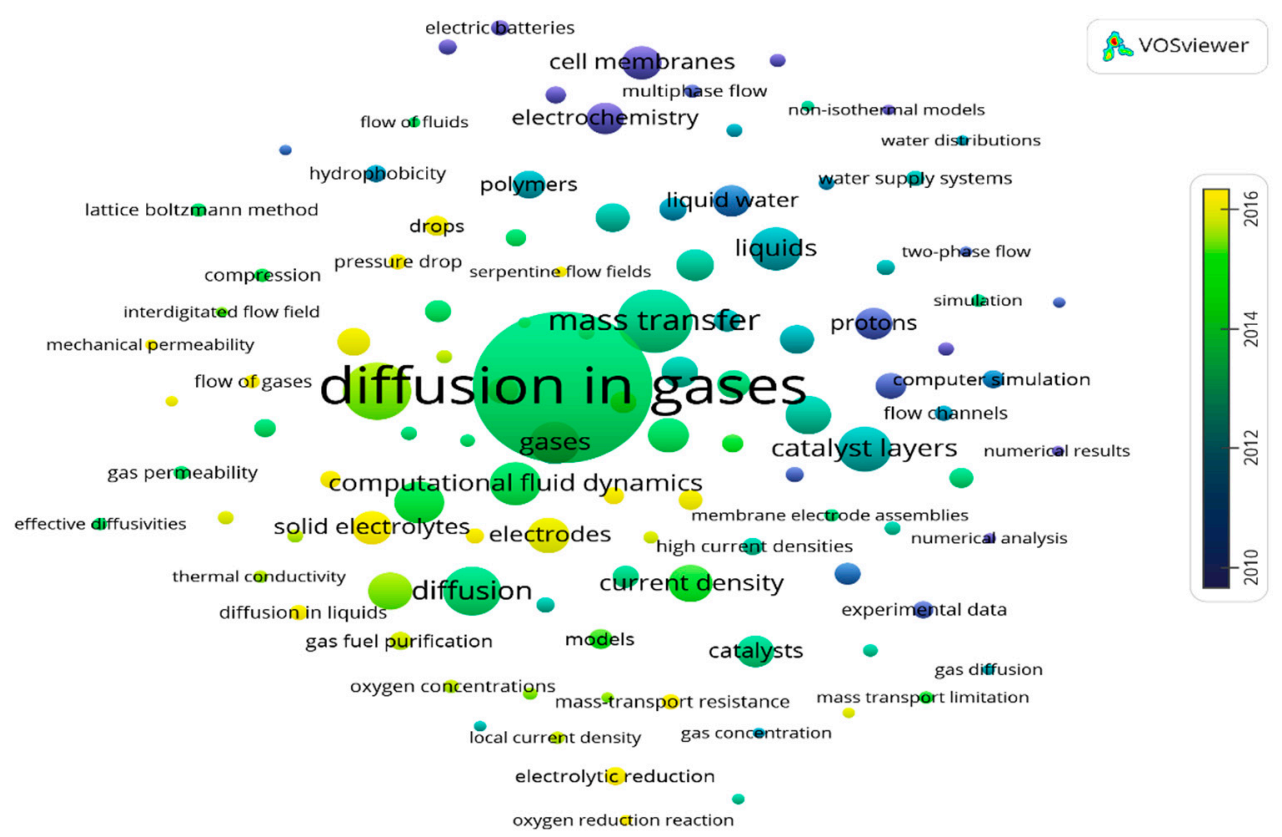

Figure 7. Bibliometric co-occurrence word map based on Mass Transport in Gas Diffusion Layer (GDL) publications.

A test with 1676 index keywords was realized. Only 140 (8.35\%) of keywords met the threshold of five or more occurrences, $40(2.38 \%)$ were used four times, $83(4.95 \%)$ keywords appeared thrice, and $1413(84.30 \%)$ keywords were used once or twice.

Over 25 years of study from 1994-2019, 932 authors participated on publications on mass transport in gas diffusion layer. Figure 8 co-authorship map displays $106(11.37 \%)$ authors with production on at least three papers. There are 34 clusters of collaboration and only one of them is composed of the largest number of elements in the groups with nine items. Likewise, 10 clusters are comprised of one author, and the most extensive collaboration network of authors consists of 51 authors corresponding to $5.47 \%$ of the sample. This behavior reveals a lack of interrelationship between the researcher groups around the world working on the theme. 


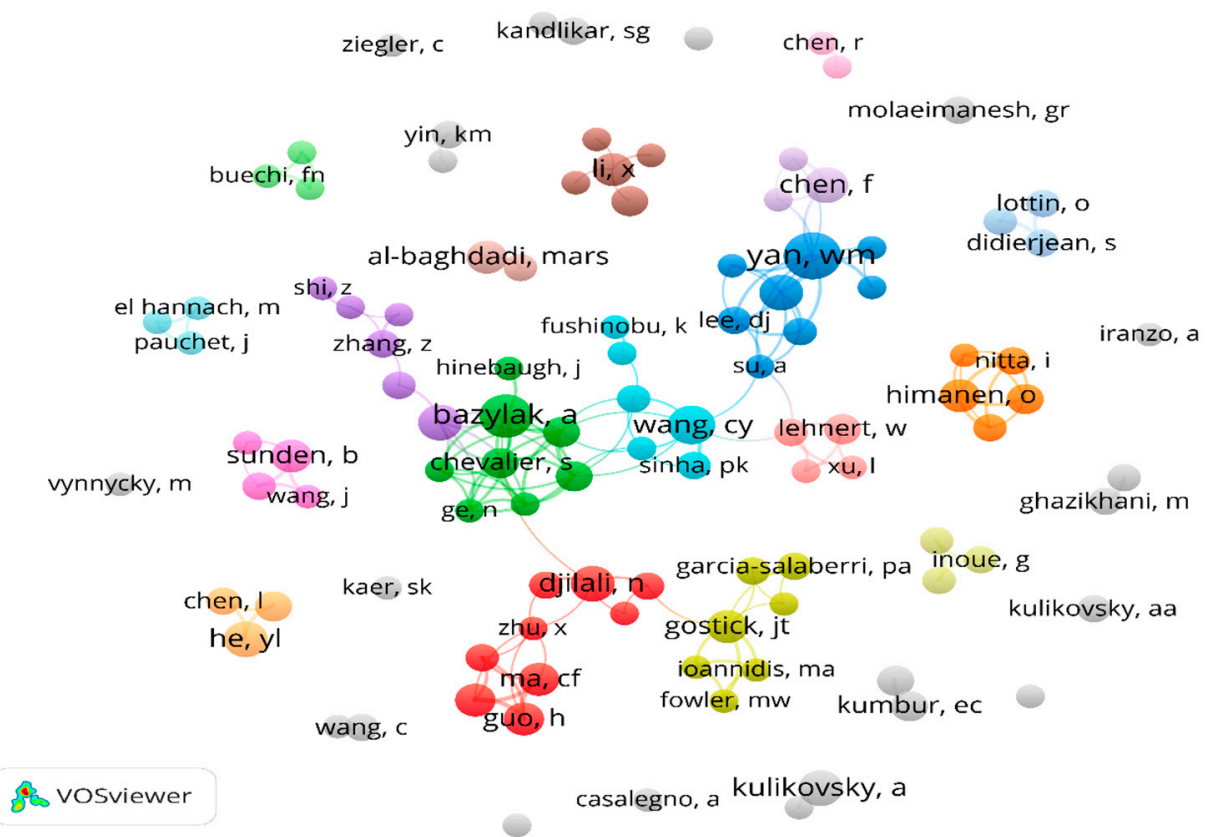

Figure 8. Bibliometric co-authorship map based on Mass Transport in GDL publications.

The most cited author is Jeff Gostick, with six articles and 632 cites, while the most productive author is Yan Wei-Mon with 12 articles and 278 citations.

A total of 412 papers classified as articles were published during a period of 25 years. Table 4 shows the annual publications in the sub-theme of the gas diffusing layer beginning in 1994 . However, there are seven years without the appearance of a new investigation document. This behavior reveals a scarce growth of the research area through the years, and the tendency has practically remained between 22 to 32 papers produced since the year 2006 .

Table 4. The number of GDL and Mass Transport publications per year.

\begin{tabular}{cccc}
\hline Year & Number of Papers & Year & Number of Papers \\
\hline 1994 & 1 & 2011 & 22 \\
2001 & 2 & 2012 & 29 \\
2003 & 4 & 2013 & 18 \\
2004 & 13 & 2014 & 24 \\
2005 & 12 & 2015 & 26 \\
2006 & 26 & 2016 & 28 \\
2007 & 28 & 2017 & 26 \\
2008 & 25 & 2018 & 29 \\
2009 & 34 & 2019 & 32 \\
2010 & 33 & & 412 \\
\hline
\end{tabular}

United States, China, and Canada are the most significant contributors to the Mass Transport in Gas Diffusion Layers in PEMFC with 90, 63 and 51 articles respectively. Additionally, they are the most cited, showing their high impact on the research. Around the world, only 44 (22.68\%) countries have been conducting studies through the period of 1994 to 2019. The co-authoring collaboration between countries is shown in the network map of Figure 9, where, once again, China, United States and Canada present the greatest partnerships with other countries. 


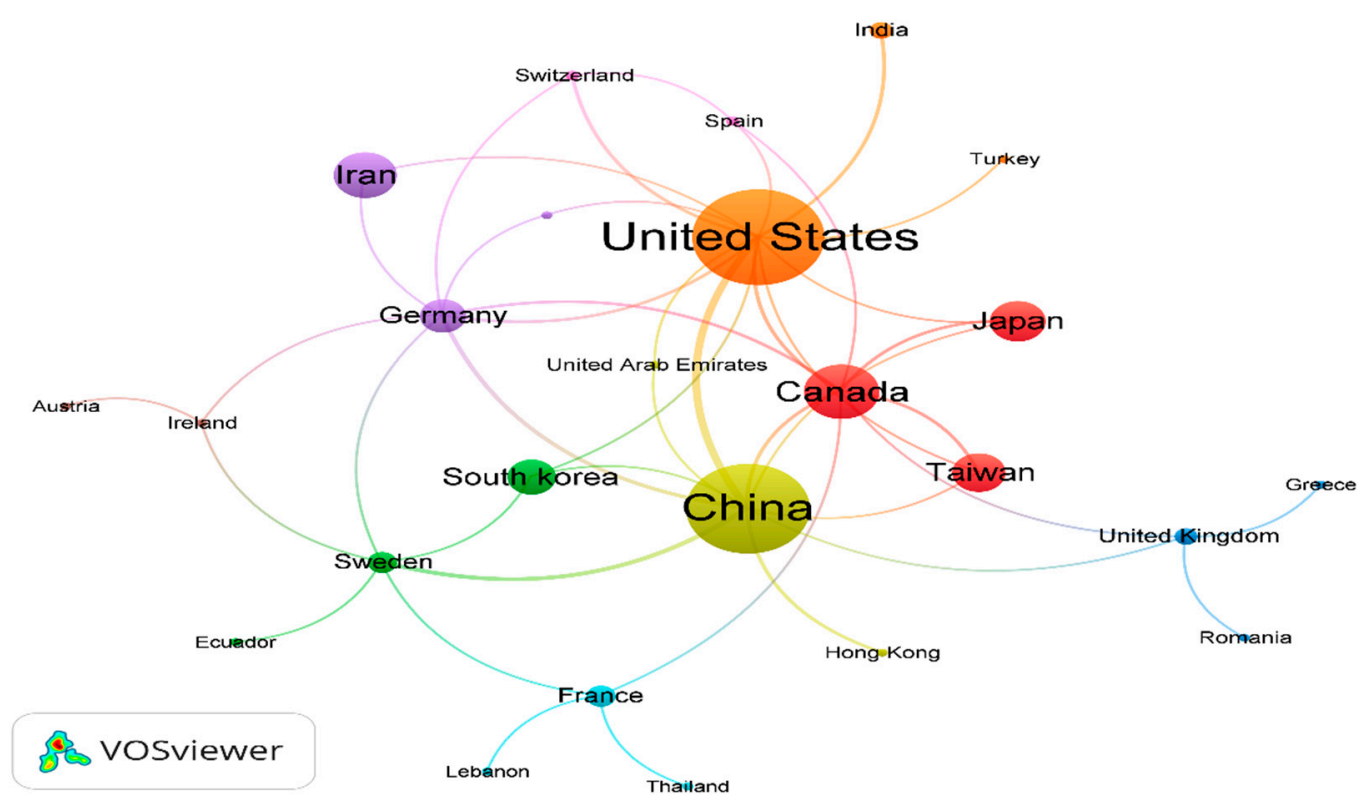

Figure 9. Bibliometric country collaboration map based on co-authorship on Mass Transport in GDL publications.

The developed research on the topic of the mass transport in gas diffusion layer has practically remained the production of papers since 2006. This topic is a very specialized research area reducing the number of researchers focused on the subject. The year 2009 had the highest productivity peak, showing a downward trend in the number of publications starting in that year. Additionally, the first scientific paper on the theme has a difference of 25 years concerning the PEMFC article. The total production of published papers (525) during the period of 1969 to 2019 represents only $1.64 \%$ of the contribution of the PEMFC articles (31,901 based on WoS).

Table 5 shows a comparison of the last ten years of the publication percentage of the mass transport in gas diffusion layer and the PEMFC area. It reveals the low contribution of articles again through the years on this subarea.

Table 5. Comparative production of the Mass Transport in GDL and PEMFC publications (WoS).

\begin{tabular}{cccc}
\hline Year & PEMFC & Mass Transport & MT/PEMFC (\%) \\
\hline 2009 & 8719 & 34 & $1.41 \%$ \\
2010 & 9718 & 33 & $1.77 \%$ \\
2011 & 9754 & 22 & $1.53 \%$ \\
2012 & 9449 & 29 & $0.99 \%$ \\
2013 & 9255 & 18 & $1.36 \%$ \\
2014 & 10,256 & 24 & $0.93 \%$ \\
2015 & 8526 & 26 & $1.13 \%$ \\
2016 & 9895 & 28 & $1.28 \%$ \\
2017 & 10,183 & 26 & $1.40 \%$ \\
2018 & 10,444 & 29 & $1.38 \%$ \\
2019 & 6940 & 32 & $1.51 \%$ \\
\hline
\end{tabular}

\subsection{Leading Journals of PEM Fuel Cell Publications}

This study analyzed which journals are the most commonly used by the researchers to disclose their works. The 31,901 documents of the WoS query for the PEMFCs were published in a total of 1676 journals. Journal of Power Sources is the leading journal in publications with 3640 papers, followed by the International Journal of Hydrogen Energy with 3203 documents. 
Table 6 lists the number of publications of the most influential journals according to WoS for each of the two search levels (PEMFC, Mass Transport in GDL). The Journal of Power Sources, the International Journal of Hydrogen Energy, and the Journal of the Electrochemical Society are located in the first three places, being thus preferred by authors for the publication of their works.

Table 6. The total de publications of leading journals.

\begin{tabular}{cccc}
\hline Ranking & Journal & PEMFC & Mass Transport \\
\hline 1 & Journal of Power Sources & 3640 & 96 \\
2 & International Journal of Hydrogen Energy & 3203 & 49 \\
3 & Journal of the Electrochemical Society & 1352 & 51 \\
4 & Electrochimica Acta & 769 & 17 \\
5 & Journal of Membrane Science & 685 & 0 \\
6 & Fuel Cells & 562 & 10 \\
7 & Journal of Fuel Cell Science and Technology & 316 & 13 \\
8 & Energy & 264 & 9 \\
9 & Applied Energy & 263 & 8 \\
10 & Energy Conversion and Management & 235 & 12 \\
\hline
\end{tabular}

The analysis of the most influential journals in the PEMFC field was generated based on the citations (Figure 10) using the VOSviewer bibliometric mapping tool. The Journal of Power Sources appears again in the first place, which allows us to confirm the importance of this journal because it took the preference of the authors to select it as the first publication option.

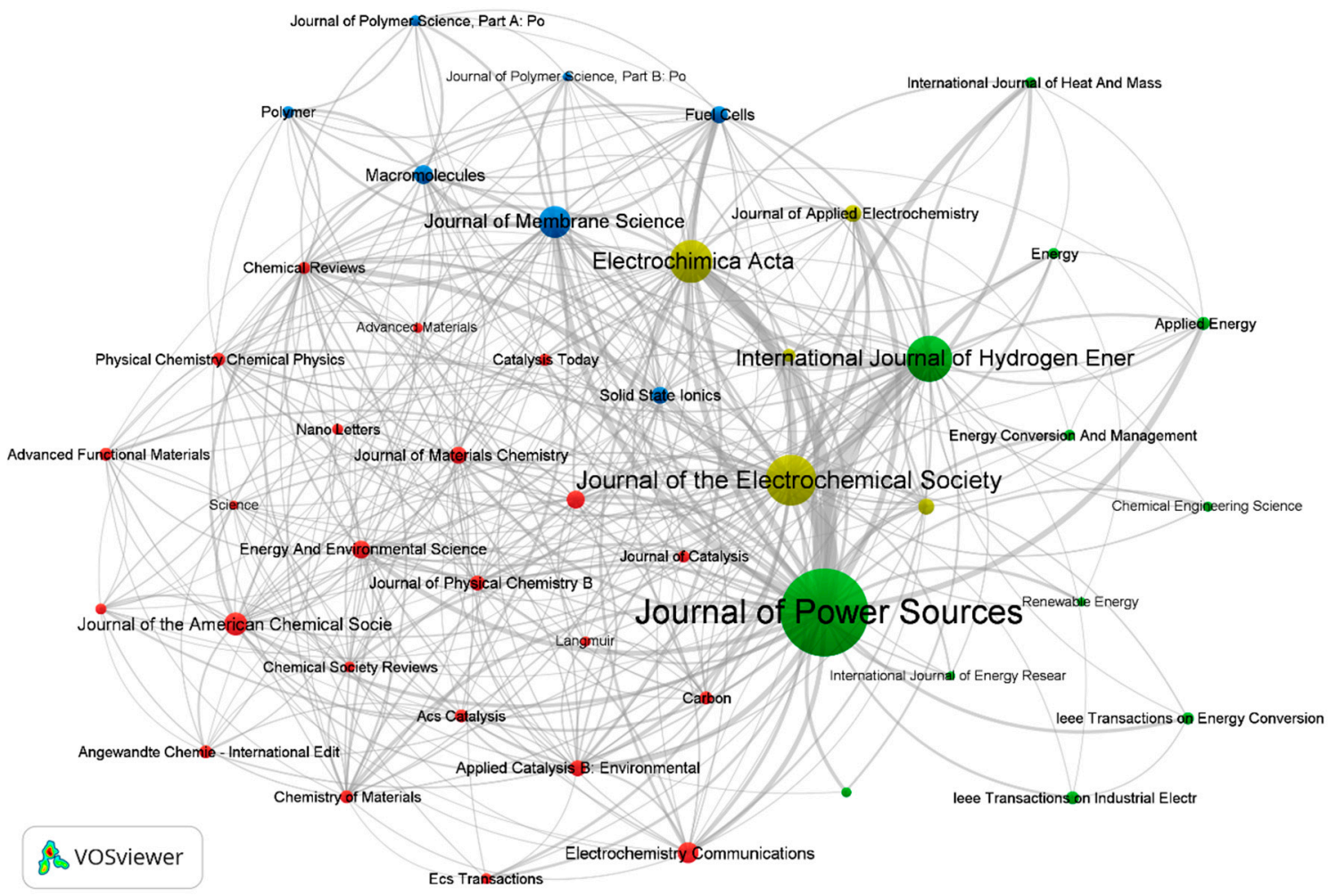

Figure 10. Bibliometric map based on citation of leading journals in PEMFC publications.

According to the classification performed by Claritive analytics in the Journal Citation Reports of the year 2018, [38,82] the Journal of Power Sources appears with an impact factor of 7.467 points, while the International Journal of Hydrogen Energy with 4.084 and the Journal of the Electrochemical Society with 3.12 points. It is important to mention that these journals are not the ones that have the highest impact factor in the ranking, but they are the main ones in terms of the number of the received citations. 
The impact factor is one of the five criteria that Methodi Ordinatio considers to ranking the articles, and it does not have a high weight in the inOrdinatio equation. Nevertheless, the researchers decided to publish in a journal based on the impact factor as a guarantee of visibility and seriousness in the investigation process. The analysis of bibliometric information provides the support to make a decision for the best options to release the results of the research work.

\section{Conclusions}

This study provided an overview analysis of the characteristics of PEM fuel cell literature using bibliometric methods to retrieve information from two major databases: Scopus and Web of Science. Bibliometrics cannot asses the research quality directly, but it is a sensor of the area of productivity since it provides indicators as the number of worldwide publications, the most cited articles, the most referenced authors, and the leading publisher countries.

Over 50 years, a total 31,901 PEMFC documents were published, the first article of PEMFC was in 1969. During this period, the growth trend has displayed the precursor, exponential, and linear phases established by the Price Law. The leading countries to productivity in this area are the United States, China, and Japan. These countries have, in common, strong spending by the business sector for R\&D, and their gross domestic product is greater than $2 \%$. There is a broad difference between the amounts spent in purchasing power parity dollars of first countries in respect to the others.

The qualitative nature of the papers is not easy to know by bibliometric indicators that allow responding to why these areas have not achieved a plateau in knowledge. However, it alerts us about the changes that occur in terms of the amount of productivity. Therefore, researchers need to determine the relevance of new issues to achieve the evolution of knowledge towards the innovation in this area.

The influence of a publication on the scientific community has been related frequently to the journal impact factor. Nevertheless, this factor is not enough to evaluate the relevance of an article that can be selected to compose the bibliographic portfolio for new research. Nowadays, the scientific population requires new strategies to facilitate selection criteria.

In regard to this situation, the methodology Methodi Ordinatio is an adequate framework that allows us to rank articles with more critical rigor, as it takes into account three article selection criteria (impact factor, year, and number of citation), and provides an organized list of relevant publications. The researchers can decide the importance degree for the year of publication by pondering alpha. This study used the Methodi Ordinatio to demonstrate the present benefits in initiating new research and decreasing the time gap to comprise a bibliographic portfolio.

Author Contributions: The following statements should be used J.C.C.A. conceived the idea of the paper subject and formal analysis; B.P.S. performed the search, applied the Methodi Ordinatio and wrote the paper; L.G.B. performed the formal analysis and wrote-original draft preparation; Z.Z. writing-review and editing; M.P.G. visualization; D.L.T. writing-review and editing supervision. The manuscript was approved by all authors for publication.

Funding: This research was funded by the Basic Science Project: “Estudio y Desarrollo de la Capa Difusora de Gas/Líquido de una Celda de Combustible Regenerativa Unificada tipo PEM" grant number 235848, CONACYT, México, 2015-2018.

Acknowledgments: We appreciate the support provided by the PhD in Information Technologies of the Universidad de Guadalajara and the Instituto Tecnológico de Chetumal.

Conflicts of Interest: The authors declare no conflicts of interest.

\section{References}

1. Haasz, T.; Vilchez, J.J.G.; Kunze, R.; Deane, P.; Fraboulet, D.; Fahl, U.; Mulholland, E. Perspectives on decarbonizing the transport sector in the EU-28. Energy Strategy Rev. 2018, 20, 124-132. [CrossRef]

2. Melikoglu, M. Clean coal technologies: A global to local review for Turkey. Energy Strategy Rev. 2018, 22, 313-319. [CrossRef] 
3. Bergen, A.; Schmeister, T.; Pitt, L.; Rowe, A.; Djilali, N.; Wild, P. Development of a dynamic regenerative fuel cell system. J. Power Sources 2007, 164, 624-630. [CrossRef]

4. Gielen, D.; Boshell, F.; Saygin, D.; Bazilian, M.D.; Wagner, N.; Gorini, R. The role of renewable energy in the global energy transformation. Energy Strategy Rev. 2019, 24, 38-50. [CrossRef]

5. Sammes, N. Fuel Cell Technology: Reaching Towards Commercialization, 1st ed.; Springer: London, UK, 2006.

6. Wang, L.; Wei, Y.M.; Brown, M.A. Global transition to low-carbon electricity: A bibliometric analysis. Appl. Energy 2017, 205, 57-68. [CrossRef]

7. Al-Baghdadi, M.A.S. Proton exchange membrane fuel cells modeling: A review of the last ten years results of the Fuel Cell Research Center-IEEF. Int. J. Energy Environ. 2017, 8, 1-28.

8. Latorrata, S.; Stampino, P.G.; Cristiani, C.; Dotelli, G. Novel superhydrophobic gas diffusion media for PEM fuel cells: Evaluation of performance and durability. Chem. Eng. 2014, 41, 241-245.

9. Rayment, C.; Sherwin, S. Introduction to Fuel Cell Technology. Dep. Aerosp. Mech. Eng. Univ. Notre Dame 2003, 46556, 11-12.

10. Samanta, I.; Shah, R.K.; Wagner, A. Fuel Processing for Fuel Applications. Fuel Cell Sci. Eng. Technol. 2004. [CrossRef]

11. Steinberger-Wilckens, R. Introduction to Fuel Cell Basics. In Advances in Medium and High Temperature Solid Oxide Fuel Cell Technology; Boaro, M., Aricò, A.S., Eds.; Springer: Cham, Switzerland, 2017; pp. 1-29.

12. Alvarado-Flores, J.; Ávalos-Rodríguez, L. Avances en el desarrollo y conocimiento del cátodo $\mathrm{Ba} 0.5 \mathrm{Sr} 0.5 \mathrm{Co} 0.8 \mathrm{Fe} 0.2 \mathrm{O}-\delta$ para celdas de combustible de óxido sólido de temperatura intermedia IT-SOFC. Rev. Mex. Fis. 2013, 59, 380-402.

13. Wu, H.W. A review of recent development: Transport and performance modeling of PEM fuel cells. Appl. Energy 2016, 165, 81-106. [CrossRef]

14. Niu, Z.; Fan, L.; Bao, Z.; Jiao, K. Numerical investigation of innovative 3D cathode flow channel in proton exchange membrane fuel cell. Int. J. Energy Res. 2018, 42, 3328-3338. [CrossRef]

15. Du, H.; Wei, L.; Brown, M.A.; Wang, Y.; Shi, Z. A bibliometric analysis of recent energy efficiency literatures: An expanding and shifting focus. Energy Effic. 2013, 6, 177-190. [CrossRef]

16. Escorcia-Otálora, T.A.; Poutou-Piñales, R.A. Análisis bibliométrico de los artículos originales publicados en la revista Universitas Scientiarum (1987-2007). Univ. Sci. 2008, 13, 236-244.

17. Jimenez-Contreras, E. Los métodos bibliométricos Estado de la cuestión y aplicaciones. In Primer Congreso Universitario de Ciencias de la Documentación; Facultad de Ciencias de la Información Universidad Complutense de Madrid: Madrid, Spain, 2000; pp. 757-771.

18. Mingers, J.; Leydesdorff, L. A review of theory and practice in scientometrics. Eur. J. Oper. Res. 2015, 246, 1-19. [CrossRef]

19. Cindrella, L.; Kannan, A.M.; Lin, J.F.; Saminathan, K.; Ho, Y.; Lin, C.W.; Wertz, J. Gas diffusion layer for proton exchange membrane fuel cells-A review. J. Power Sources 2009, 194, 146-160. [CrossRef]

20. Cindrella, L.; Fu, H.Z.; Ho, Y.S. Global thrust on fuel cells and their sustainability-an assessment of research trends by bibliometric analysis. Int. J. Sustain. Energy 2014, 33, 125-140. [CrossRef]

21. Huang, M.H.; Yang, H.W. A Scientometric Study of Fuel Cell Based on Paper and Patent Analysis. J. Libr. Inf. Stud. 2013, 11, 1-24.

22. OECD. Innovation in Fuel Cells: A Bibliometric Analysis; Organisation for Economic Co-operation and Development Publications: Paris, France, 2005.

23. Chen, H.Q.; Wang, X.; He, L.; Chen, P.; Wan, Y.; Yang, L.; Jiang, S. Chinese energy and fuels research priorities and trend: A bibliometric analysis. Renew. Sustain. Energy Rev. 2016, 58, 966-975. [CrossRef]

24. Ho, M.H.C.; Lin, V.H.; Liu, J.S. Exploring knowledge diffusion among nations: A study of core technologies in fuel cells. Scientometrics 2014, 100, 149-171. [CrossRef]

25. Ogawa, T.; Kajikawa, Y. Assessing the industrial opportunity of academic research with patent relatedness: A case study on polymer electrolyte fuel cells. Technol. Forecast. Soc. Chang. 2015, 90, 469-475. [CrossRef]

26. Spiegel, C. PEM Fuel Cell: Modeling and Simulation Using MATLAB; Academic Press/Elsevier: Amsterdam, The Netherlands, 2008. [CrossRef]

27. Truc, N.T.; Ito, S.; Fushinobu, K. Numerical and experimental investigation on the reactant gas crossover in a PEM fuel cell. Int. J. Heat Mass Transf. 2018, 127, 447-456. [CrossRef] 
28. Wan, Z.H.; Zhong, Q.; Liu, S.F.; Jin, A.P.; Chen, Y.N.; Tan, J.T.; Pan, M. Determination of oxygen transport resistance in gas diffusion layer for polymer electrolyte fuel cells. Int. J. Energy Res. 2018, 42, 2225-2233. [CrossRef]

29. Zhang, G.; Xie, B.; Bao, Z.; Niu, Z.; Jiao, K. Multi-phase simulation of proton exchange membrane fuel cell with 3D fine mesh flow field. Int. J. Energy Res. 2018, 42, 4697-4709. [CrossRef]

30. Pagani, R.N.; Kovaleski, J.L.; Resende, L.M. Methodi Ordinatio: A proposed methodology to select the impact factor, number of citation, and year of publication. Scientometrics 2015, 105, 2109-2135. [CrossRef]

31. De Campos, E.A.R.; Pagani, R.N.; Resende, L.M.; Pontes, J. Construction and qualitative assessment of a bibliographic portfolio using the methodology Methodi Ordinatio. Scientometrics 2018, 116, 815-842. [CrossRef]

32. Aghaei Chadegani, A.; Salehi, H.; Yunus, M.; Farhadi, H.; Fooladi, M.; Farhadi, M.; Ale Ebrahim, N. A Comparison between Two Main Academic Literature Collections: Web of Science and Scopus Databases. Asian Soc. Sci. 2013, 9, 18-26. [CrossRef]

33. Khudzari, J.M.; Kurian, J.; Tartakovsky, B.; Raghavan, G.V. Bibliometric analysis of global research trends on microbial fuel cells using Scopus database. Biochem. Eng. J. 2018, 136, 51-60. [CrossRef]

34. Harzing, A.W.; Alakangas, S. Google Scholar, Scopus and the Web of Science: A longitudinal and cross-disciplinary comparison. Scientometrics 2016, 106, 787-804. [CrossRef]

35. Vieira, E.S.; Gomes, J.A. A comparison of Scopus and Web of Science for a typical university. Scientometrics 2009, 81, 587-600. [CrossRef]

36. Van Eck, N.; Waltman, L. Software survey: VOSviewer, a computer program for bibliometric mapping. Scientometrics 2010, 84, 523-538. [CrossRef]

37. Van Eck, N.J.; Waltman, L. VOSviewer Manual; Univeristeit Leiden: Leiden, The Netherlands, 2013.

38. Claritive Analytics Journal Citation Reports. Available online: https://jcr.incites.thomsonreuters.com/ JCRJournalHomeAction.action (accessed on 3 October 2019).

39. Scimago, S.J.R. Scientific Journal Rankings. Available online: https://www.scimagojr.com/journalrank.php (accessed on 14 October 2019).

40. Urbizagástegui Alvarado, R. El crecimiento de la literatura sobre la ley de Bradford. Investig. Bibl. 2016, 30, 51-72.

41. Lee, J.; Yang, J.S. Government R \& D investment decision-making in the energy sector: LCOE foresight model reveals what regression analysis cannot. Energy Strategy Rev. 2018, 21, 1-15.

42. Suominen, A. Phases of growth in a green tech research network: A bibliometric evaluation of fuel cell technology from 1991 to 2010. Scientometrics 2014, 100, 51-72. [CrossRef]

43. Trianni, A.; Merigó, J.M.; Bertoldi, P. Ten years of Energy Efficiency: A bibliometric analysis. Energy Effic. 2018, 11, 1917-1939. [CrossRef]

44. UNESCO. How Much Does Your Country Spend on RED? UNESCO Innsitute for Statistics, 2018. Available online: http://uis.unesco.org/apps/visualisations/research-and-development-spending/ (accessed on 15 October 2019).

45. Carton, J.G.; Lawlor, V.; Olabi, A.G.; Hochenauer, C.; Zauner, G. Water droplet accumulation and motion in PEM (Proton Exchange Membrane) fuel cell mini-channels. Energy 2012, 39, 63-73. [CrossRef]

46. Mukherjee, P.P.; Wang, C.Y.; Kang, Q. Mesoscopic modeling of two-phase behavior and flooding phenomena in polymer electrolyte fuel cells. Electrochim. Acta 2009, 54, 6861-6875. [CrossRef]

47. Chen, L.; Luan, H.B.; He, Y.L.; Tao, W.Q. Pore-scale flow and mass transport in gas diffusion layer of proton exchange membrane fuel cell with interdigitated flow fields. Int. J. Therm. Sci. 2012, 51, 132-144. [CrossRef]

48. Jahnke, T.; Futter, G.; Latz, A.; Malkow, T.; Papakonstantinou, G.; Tsotridis, G.; Schott, P.; Gérard, M.; Quinaud, M.; Quiroga, M.; et al. Performance and degradation of Proton Exchange Membrane Fuel Cells: State of the art in modeling from atomistic to system scale. J. Power Sources 2016, 304, 207-233. [CrossRef]

49. Hao, L.; Cheng, P. Lattice Boltzmann simulations of water transport in gas diffusion layer of a polymer electrolyte membrane fuel cell. J. Power Sources 2010, 195, 3870-3881. [CrossRef]

50. Ramasamy, R.P.; Kumbur, E.C.; Mench, M.M.; Liu, W.; Moore, D.; Murthy, M. Investigation of macro- and micro-porous layer interaction in polymer electrolyte fuel cells. Int. J. Hydrogen Energy 2008, 33, 3351-3367. [CrossRef]

51. Sinha, P.K.; Wang, C.Y. Liquid water transport in a mixed-wet gas diffusion layer of a polymer electrolyte fuel cell. Chem. Eng. Sci. 2008, 63, 1081-1091. [CrossRef] 
52. Zhu, X.; Sui, P.C.; Djilali, N. Three-dimensional numerical simulations of water droplet dynamics in a PEMFC gas channel. J. Power Sources 2008, 181, 101-115. [CrossRef]

53. Hizir, F.E.; Ural, S.O.; Kumbur, E.C.; Mench, M.M. Characterization of interfacial morphology in polymer electrolyte fuel cells: Micro-porous layer and catalyst layer surfaces. J. Power Sources 2010, 195, 3463-3471. [CrossRef]

54. Hwang, G.S.; Weber, A.Z. Effective-Diffusivity Measurement of Partially-Saturated Fuel-Cell Gas-Diffusion Layers. J. Electrochem. Soc. 2012, 159, F683-F692. [CrossRef]

55. Koido, T.; Furusawa, T.; Moriyama, K. An approach to modeling two-phase transport in the gas diffusion layer of a proton exchange membrane fuel cell. J. Power Sources 2008, 175, 127-136. [CrossRef]

56. García-Salaberri, P.A.; Gostick, J.T.; Hwang, G.; Weber, A.Z.; Vera, M. Effective diffusivity in partially-saturated carbon-fiber gas diffusion layers: Effect of local saturation and application to macroscopic continuum models. J. Power Sources 2015, 296, 440-453. [CrossRef]

57. Luo, Y.; Jiao, K. Cold start of proton exchange membrane fuel cell. Prog. Energy Combust. Sci. 2018, 64, $29-61$. [CrossRef]

58. Kleemann, J.; Finsterwalder, F.; Tillmetz, W. Characterisation of mechanical behaviour and coupled electrical properties of polymer electrolyte membrane fuel cell gas diffusion layers. J. Power Sources 2009, 190, 92-102. [CrossRef]

59. Heidary, H.; Kermani, M.J.; Dabir, B. Influences of bipolar plate channel blockages on PEM fuel cell performances. Energy Convers. Manag. 2016, 124, 51-60. [CrossRef]

60. Zamel, N.; Astrath, N.G.; Li, X.; Shen, J.; Zhou, J.; Astrath, F.B.; Wang, H.; Liu, Z.S. Experimental measurements of effective diffusion coefficient of oxygen-nitrogen mixture in PEM fuel cell diffusion media. Chem. Eng. Sci. 2010, 65, 931-937. [CrossRef]

61. Cao, T.F.; Lin, H.; Chen, L.; He, Y.L.; Tao, W.Q. Numerical investigation of the coupled water and thermal management in PEM fuel cell. Appl. Energy 2013, 112, 1115-1125. [CrossRef]

62. Pant, L.M.; Mitra, S.K.; Secanell, M. Absolute permeability and Knudsen diffusivity measurements in PEMFC gas diffusion layers and micro porous layers. J. Power Sources 2012, 206, 153-160. [CrossRef]

63. Park, J.; Oh, H.; Lee, Y.I.; Min, K.; Lee, E.; Jyoung, J.Y. Effect of the pore size variation in the substrate of the gas diffusion layer on water management and fuel cell performance. Appl. Energy 2016, 171, 200-212. [CrossRef]

64. Kandlikar, S.G.; Lu, Z.; Domigan, W.E.; White, A.D.; Benedict, M.W. Measurement of flow maldistribution in parallel channels and its application to ex-situ and in-situ experiments in PEMFC water management studies. Int. J. Heat Mass Transf. 2009, 52, 1741-1752. [CrossRef]

65. Zenyuk, I.V.; Lamibrac, A.; Eller, J.; Parkinson, D.Y.; Marone, F.; Buchi, F.N.; Weber, A.Z. Investigating Evaporation in Gas Diffusion Layers for Fuel Cells with X-ray Computed Tomography. J. Phys. Chem. C 2016, 120, 28701-28711. [CrossRef]

66. Jiao, K.; Li, X. Three-dimensional multiphase modeling of cold start processes in polymer electrolyte membrane fuel cells. Electrochim. Acta 2009, 54, 6876-6891. [CrossRef]

67. Kim, K.N.; Kang, J.H.; Lee, S.G.; Nam, J.H.; Kim, C.J. Lattice Boltzmann simulation of liquid water transport in microporous and gas diffusion layers of polymer electrolyte membrane fuel cells. J. Power Sources 2015, 278, 703-717. [CrossRef]

68. Chang, T.C.; Zhang, J.P.; Fuh, Y.K. Electrical, mechanical and morphological properties of compressed carbon felt electrodes in vanadium redox flow battery. J. Power Sources 2014, 245, 66-75. [CrossRef]

69. Kim, J.; Luo, G.; Wang, C.Y. Modeling two-phase flow in three-dimensional complex flow-fields of proton exchange membrane fuel cells. J. Power Sources 2017, 365, 419-429. [CrossRef]

70. Zhang, D.; Cai, Q.; Gu, S. Three-dimensional lattice-Boltzmann model for liquid water transport and oxygen diffusion in cathode of polymer electrolyte membrane fuel cell with electrochemical reaction. Electrochim. Acta 2018, 262, 282-296. [CrossRef]

71. Chevalier, S.; Lee, J.; Ge, N.; Yip, R.; Antonacci, P.; Tabuchi, Y.; Kotaka, T.; Bazylak, A. In operando measurements of liquid water saturation distributions and effective diffusivities of polymer electrolyte membrane fuel cell gas diffusion layers. Electrochim. Acta 2016, 210, 792-803. [CrossRef]

72. Zhang, S.; Reimer, U.; Beale, S.B.; Lehnert, W.; Stolten, D. Modeling polymer electrolyte fuel cells: A high precision analysis. Appl. Energy 2019, 233, 1094-1103. [CrossRef] 
73. Hao, L.; Cheng, P. Lattice Boltzmann simulations of liquid droplet dynamic behavior on a hydrophobic surface of a gas flow channel. J. Power Sources 2009, 190, 435-446. [CrossRef]

74. Tsai, B.T.; Tseng, C.J.; Liu, Z.S.; Wang, C.H.; Lee, C.I.; Yang, C.C.; Lo, S.K. Effects of flow field design on the performance of a PEM fuel cell with metal foam as the flow distributor. Int. J. Hydrogen Energy 2012, 37, 13060-13066. [CrossRef]

75. Xing, L.; Xu, Y.; Das, P.K.; Mao, B.; Xu, Q.; Su, H.; Wu, X.; Shi, W. Numerical matching of anisotropic transport processes in porous electrodes of proton exchange membrane fuel cells. Chem. Eng. Sci. 2019, 195, 127-140. [CrossRef]

76. Xu, L.; Fang, C.; Li, J.; Ouyang, M.; Lehnert, W. Nonlinear dynamic mechanism modeling of a polymer electrolyte membrane fuel cell with dead-ended anode considering mass transport and actuator properties. Appl. Energy 2018, 230, 106-121. [CrossRef]

77. Chevalier, S.; Josset, C.; Auvity, B. Analytical solutions and dimensional analysis of pseudo 2D current density distribution model in PEM fuel cells. Renew. Energy 2018, 125, 738-746. [CrossRef]

78. Chen, L.; Feng, Y.L.; Song, C.X.; Chen, L.; He, Y.L.; Tao, W.Q. Multi-scale modeling of proton exchange membrane fuel cell by coupling finite volume method and lattice Boltzmann method. Int. J. Heat Mass Transf. 2013, 63, 268-283. [CrossRef]

79. Espinoza-Andaluz, M.; Andersson, M.; Sundén, B. Comparing through-plane diffusibility correlations in PEFC gas diffusion layers using the lattice Boltzmann method. Int. J. Hydrogen Energy 2017, 42, 11689-11698. [CrossRef]

80. Swamy, T.; Kumbur, E.C.; Mench, M.M. Characterization of Interfacial Structure in PEFCs: Water Storage and Contact Resistance Model. J. Electrochem. Soc. 2010, 157, B77-B85. [CrossRef]

81. Movahedi, M.; Ramiar, A.; Ranjber, A.A. 3D numerical investigation of clamping pressure effect on the performance of proton exchange membrane fuel cell with interdigitated flow field. Energy 2018, 142, 617-632. [CrossRef]

82. Yin, J.; Gong, L.; Wang, S. Large-scale assessment of global green innovation research trends from 1981 to 2016: A bibliometric study. J. Clean. Prod. 2018, 197, 827-841. [CrossRef]

(C) 2019 by the authors. Licensee MDPI, Basel, Switzerland. This article is an open access article distributed under the terms and conditions of the Creative Commons Attribution (CC BY) license (http://creativecommons.org/licenses/by/4.0/). 